\title{
A Content and Citation Analysis of the Studies on Learning Environments and Special Education
}

\author{
Huseyin Uzunboylu1,2*, Gönül Akçamete ${ }^{1}$ \\ ${ }^{1}$ Near East University, Cyprus, Mersin 10 Turkey, e-mail: huseyin.uzunboylu@gmail.com \\ ${ }^{2}$ Higher Education Planning, Supervision, Accreditation and Coordination Board, Nicosia, Cyprus, Mersin 10, Turkey, \\ e-mail: gonul.akcamete@neu.edu.tr
}

\begin{abstract}
This study aims to review the studies on learning environments and special education and determine the trends in these studies. Content and citation analysis were used which is a qualitative research method. Data of the study were collected from Scopus with 'learning environment' and 'special education' keywords 180 documents were collected. For the analysis of the published documents, previously determined content analysis criteria were used and citation analysis of the published documents were carried out, in order to reveal the frequently cited documents. Documents were examined based on year of publication, name of the journals, authors, affiliations, countries, document type, subject area, keywords, language and citations. Data were presented and interpreted with tables and figures. Results were presented in detail with reference to the previous literature.
\end{abstract}

Keywords: Learning environment, evaluation, special education, content analysis, citation analysis.

\section{Introduction}

Educational opportunities provided to students with special needs are increasing day by day and more students in the last decade benefit from these possibilities (Coskun and Mitrani, 2020; Lewis, Wheeler and Carter, 2017). In the past, when it comes to education of students with special needs, it was considered that education should be in separate schools and students would be placed in schools or special education classes. On the other hand, mainstreaming and inclusive practices have increased in recent years and students with special needs have the opportunity to receive education with their peers and participate in social life more frequently (Gozun and Yikmis, 2004; Kaya et al., 2017). In order to meet the educational needs of individuals in need of special education, instructional practices are adapted for them in line with their diagnosis, disability characteristics and needs (Akcamete, Kayhan and Yildirim, 2017; Ozcan and Merdan, 2016).

The aim of the training of special needs individuals is to ensure that individuals with special needs are as independent as possible in their lives and that they can maintain a qualified life (Ardic, 2014). Special adaptations are required for educational environments for children with special needs. Therefore, in order for their needs to be met, it is necessary to know well who these children are and how their needs will be met. The characteristics of the individuals in the total disability group show differences. Dixon et all., (2014) stated that it is very important to know the characteristics of the individuals well, to evaluate the individuals correctly, to determine the performance levels well, to place them in the appropriate educational environments, to prepare the appropriate training programmes and to support them.

Evaluation in special education is the process of collecting data to determine the academic, behavioural or physical characteristics of individuals and make decisions according to those characteristics. It includes the systematic compilation of important information in terms of education to be used to make legal and educational decisions regarding the provision of special services and determine learning objectices (Avcioglu, 2016; Bateman and Bateman, 2014). Today, evaluation in special education is shaped by the individual needs of each student with special needs. After an appropriate evaluation process and decision regarding the needs of the students with special needs, individualized education programmes will be prepared to increase and improve the performance level of the students to be able to gain functional skills, live and maintain their daily lives independently. Learning environment is "Corresponding author: huseyin.uzunboylu@gmail.com 
very important for improving learning and teaching practices (Ince and Costu, 2018) and based on a comprehensive evaluation process, learning environments could be designed and prepared for students with special needs. In addition, Sancar, Tozkoparan and Odabasi (2017) reviewed content analysis of scientific articles on the use of mobile technologies in special education.

According to the regulation of special education services in Turkey and based on the various legislations worldwide, educational evaluation and diagnosis are done at an early age (Milli Egitim Bakanligi, 2006; Sahin and Koca, 2017). Educational evaluation and identification are achieved through assessing the individual's characteristics in all developmental areas and their academic qualifications in the disciplinary fields and educational needs together. It is very important to provide physical, social, educational and psychological care for the individual in the most appropriate environment (Mostafa, 2017).

In recent years, one of the most discussed topics in the field of special education has been the provision of services in the least restrictive environment. The least restrictive educational environment principle is that needs of students with special needs should be placed in an educational environment that will ensure that it will meet the needs of the students in the most appropriate ways. Individual learning environments need to be sufficient and inadequate for the needs and characteristics of the invidiuals with special needs (Crockett and Kauffman, 2013; Taylor, 2004; Sabayleh and Alramamneh, 2020).

Educational evaluation is also a part of the ongoing interdisciplinary effort to understand the needs of individuals with special needs. Evaluation in special education is a teamwork and this team involves a special education teacher, a psychologist, a speech therapist and other professionals working in the field of special education (Howe and Miramontes, 2015; Uzunboylu et al., 2017). As it can be seen, the evaluation process and learning environments in special education have a crucial place. Therefore, examination of the results of scientific research on this subject and identification of trends in this area will reveal the current situation and development, and it is expected that this would provide a guidance for further special education research and practices, especially in terms of providing appropriate learning objectives and environments for individuals with special needs. Therefore, this study aims to review the studies on learning environments and special education and determine the trends in these studies.

\section{Materials and methods}

\section{Research model}

Content analysis and citation analysis as one of the most frequently used qualitative research methods were used in this study. According to Vasiliene-Vasiliauskiene et al., (2020), Cohen, Manion and Morrison (2007), content analysis is the process of summarizing and expressing the basic contents of the verbal or written information and the messages they contain. It is aimed to reveal the hidden truths contained in the data and definition of the data through content analysis (Gulbahar and Alper, 2009; Inaltekin, 2020). Content analysis involves four stages: processing of qualitative research data obtained from documents, organisation of the data and interpretation of findings (Zaid, 2020; Uzunboylu and Beheshti, 2017). Nevertheless, citation analysis has become prevalent as a parameter for evaluating the quality of published research in a specific field, and it reveals the historical and current situation of the research in that field (Atilgan, Atakan and Bulut, 2008; Leung, Sun and Bai, 2017).

\section{Data collection}

Data of the study were obtained through searching Scopus with 'learning environment' and 'special education' and relevant documents were included in the study. Learning environments and special education search page in Scopus is provided in Figure 1. 


\section{Figure 1.}

Learning environments and special education search page screen in Scopus

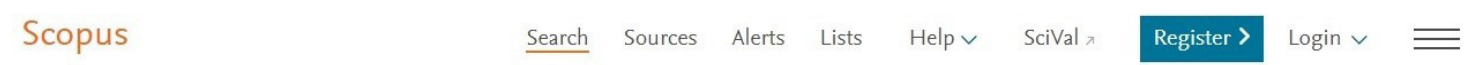

\section{0 document results}

(TITLE-ABS-KEY ("learning environment" ) AND TITLE-ABS-KEY ("special education"))

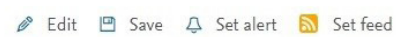

Search within results...

Refine results

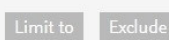

Access type (1)

$\square$ Open Access

$\square$ Other aln Analyze search results

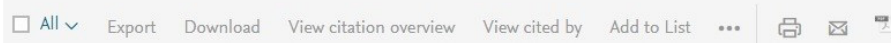

Document title

The impact of the institutional learning environments Kantor, V.Z.,

on the development of self-attitude in pupils with Nikulina, G.V.,

vision deficiency

View abstract $\vee$ Related documents
Year Source

2017 Journal of Pharmaceutical

Sciences and Research

2017 European Journal of Special Needs Education

\section{Data analysis}

Content analysis criteria were indicated to review the collected data. The criteria were year of publication, name of the journals, authors, universities, countries, document type, subject area, keywords and language. In addition, most cited papers were also identified and mentioned in the results.

180 documents were analysed based on the collected data. Results were examined according to content analysis criteria.

\section{Results}

\section{Distribution of the published documents based on the year of publication}

Figure 2.

Distribution of the published documents based on the year of publication

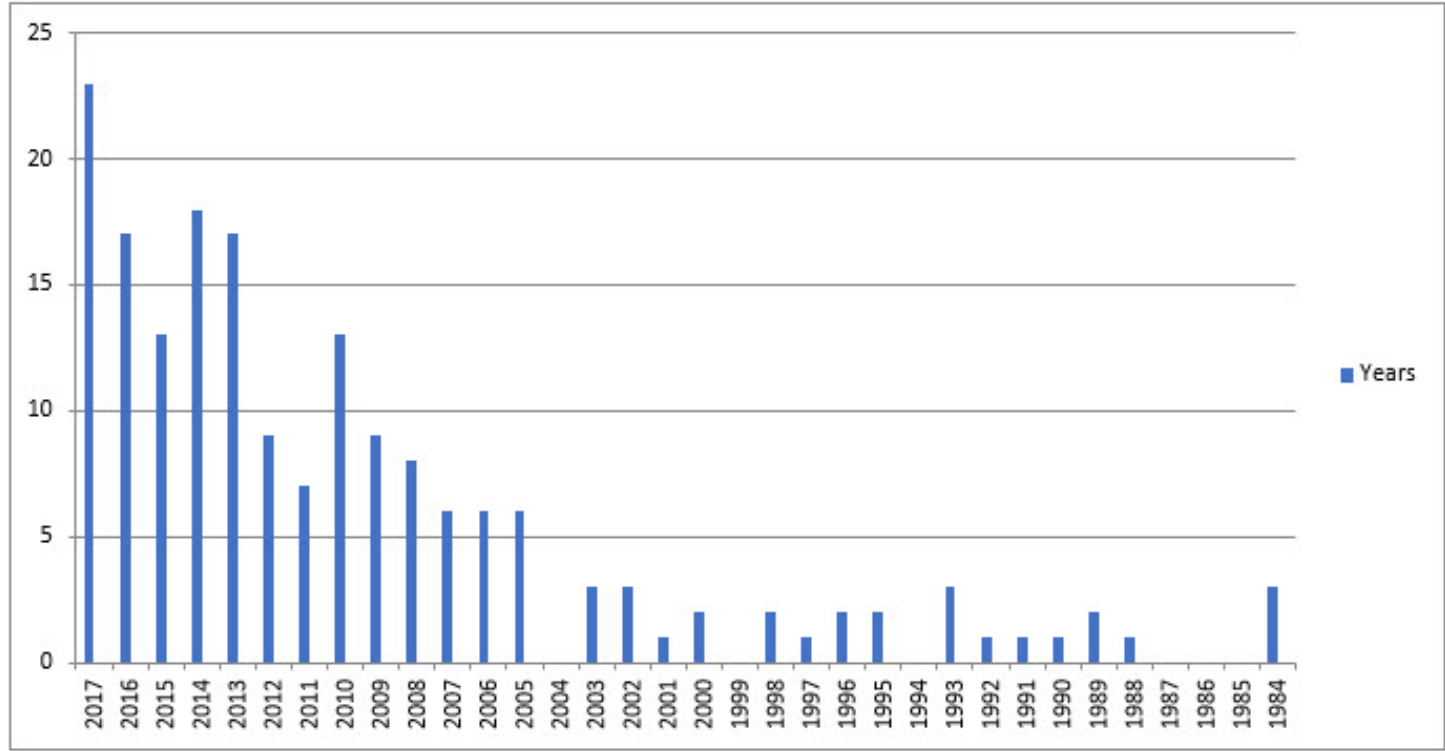

Figure 2 provides the distribution of the published documents on learning environments and special education based on the year of publication. Results showed that published documents are distributed between the years of 1980 and 2017 as demonstrated in the figure and there are no publications in 1985, 1986, 1987, 1994, 1999 and 2004 out of the 180 documents examined in the study. The number of 
published documents increased regularly especially after 2005 when compared to previous years and the highest number of publication is in 2017 with 23 publications.

\section{Distribution of the published documents based on the name of the journals}

\section{Table 1.}

Name of the journals in which the documents published

\begin{tabular}{lll}
\hline Name of the journals & $f$ & $\%$ \\
\hline European Journal of Special Needs Education & 20 & 11.11 \\
Lecture Notes in Computer Science & 7 & 3.89 \\
International Journal of Inclusive Education & 6 & 3.33 \\
Remedial and Special Education & 5 & 2.78 \\
British Journal of Special Education & 4 & 2.22 \\
Computers And Education & 4 & 2.22 \\
Exceptional Children & 4 & 2.22 \\
Journal of Research in Special Educational & 4 & 2.22 \\
Needs & & \\
Journal of Special Education & 3 & 1.67 \\
Revista Brasileira de Educacao Especial & 3 & 1.67 \\
American Journal of Distance Education & 2 & 1.11 \\
Education and Information Technologies & 2 & 1.11 \\
Emotional and Behavioral Difficulties & 2 & 1.11 \\
International Journal of Learning & 2 & 1.11 \\
International Journal of Special Education & 2 & 1.11 \\
Intervention in School and Clinic & 2 & 1.11 \\
Journal of Autism and Developmental Disorders & 2 & 1.11 \\
Technology and Disability & 2 & 1.11 \\
World Academy of Science Engineering and & 2 & 1.11 \\
Technology & & \\
Other Journals & 78 & 43.33 \\
Total & 180 & 100 \\
\hline
\end{tabular}

Table 1 shows the name of the journals in which the documents related with learning environments and special education were published. The first 19 journal names are shown in the table, because the frequency of other journals was one and these journals constituted $43.33 \%$ of the 180 documents. The highest number of publications is in European Journal of Special Needs Education ( $f=20,11.11 \%$ ). This result is followed by Lecture Notes in Computer Science with seven publications (3.89\%); International Journal of Inclusive Education with six publications (3.33\%) and Remedial and Special Education with five publications $(2.78 \%)$.

\section{Results on the names and affiliations of the authors}

Results on names and affiliations were not shown in table or figure, because their frequencies were one or two and it would not be possible to demonstrate in a table or figure. According to the results, Oslo University and Helsinki University are the mostly observed academic institutions which are mentioned as affiliations in the published documents and the others were only with one and two frequencies. No steady trend was observed in the names and affiliations of authors. 


\section{Distribution of the published documents based on the countries}

Figure 3.

Countries of the publications

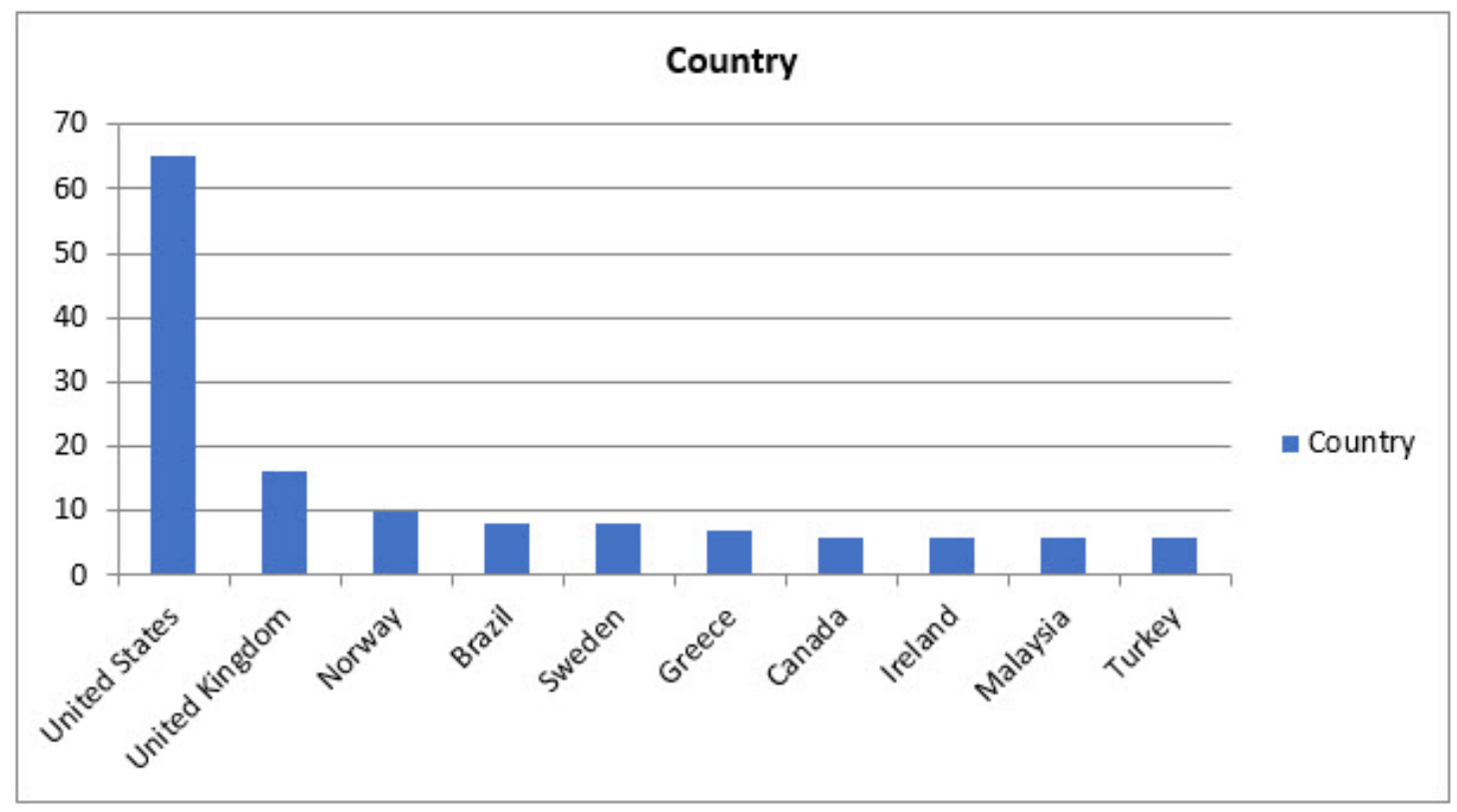

Distribution based on the countries of the publications is presented in Figure 3. The top 10 countries were included in the figure, because the other countries were with one frequency. Results showed that the United States is the first country with 65 publications related with learning environments and special education in Scopus. The United Kingdom, Norway, Brazil, Sweden, Greece, Canada, Ireland, Malaysia and Turkey were the other countries with the highest number of publications

\section{Distribution of the published documents based on the document type}

\section{Table 2.}

Document types of the published documents

\begin{tabular}{lll}
\hline Document type & $f$ & $\%$ \\
\hline Article & 125 & 69.44 \\
Conference paper & 25 & 13.89 \\
Book & 11 & 6.11 \\
Book chapter & 9 & 5.00 \\
& & \\
Review & 6 & 3.33 \\
Article in press & 2 & 1.11 \\
Conference review & 1 & 0.56 \\
Note & 1 & 0.56 \\
Total & $\mathbf{1 8 0}$ & $\mathbf{1 0 0}$ \\
\hline
\end{tabular}

Table 2 shows the document types of the published documents. Most of the published documents were articles ( $f=125,69.44 \%$ ). Therefore, it can be determined that authors choose to publish research articles rather than other types of documents. It was also revealed that conference paper $(f=25,13.89 \%)$, book $(f=11,6.11 \%)$ and book chapter $(f=9,5.00 \%)$ were also frequently mentioned document types. 


\section{Distribution of the published documents based on the subject area}

Figure 4.

Frequency distribution of the published documents based on the subject area

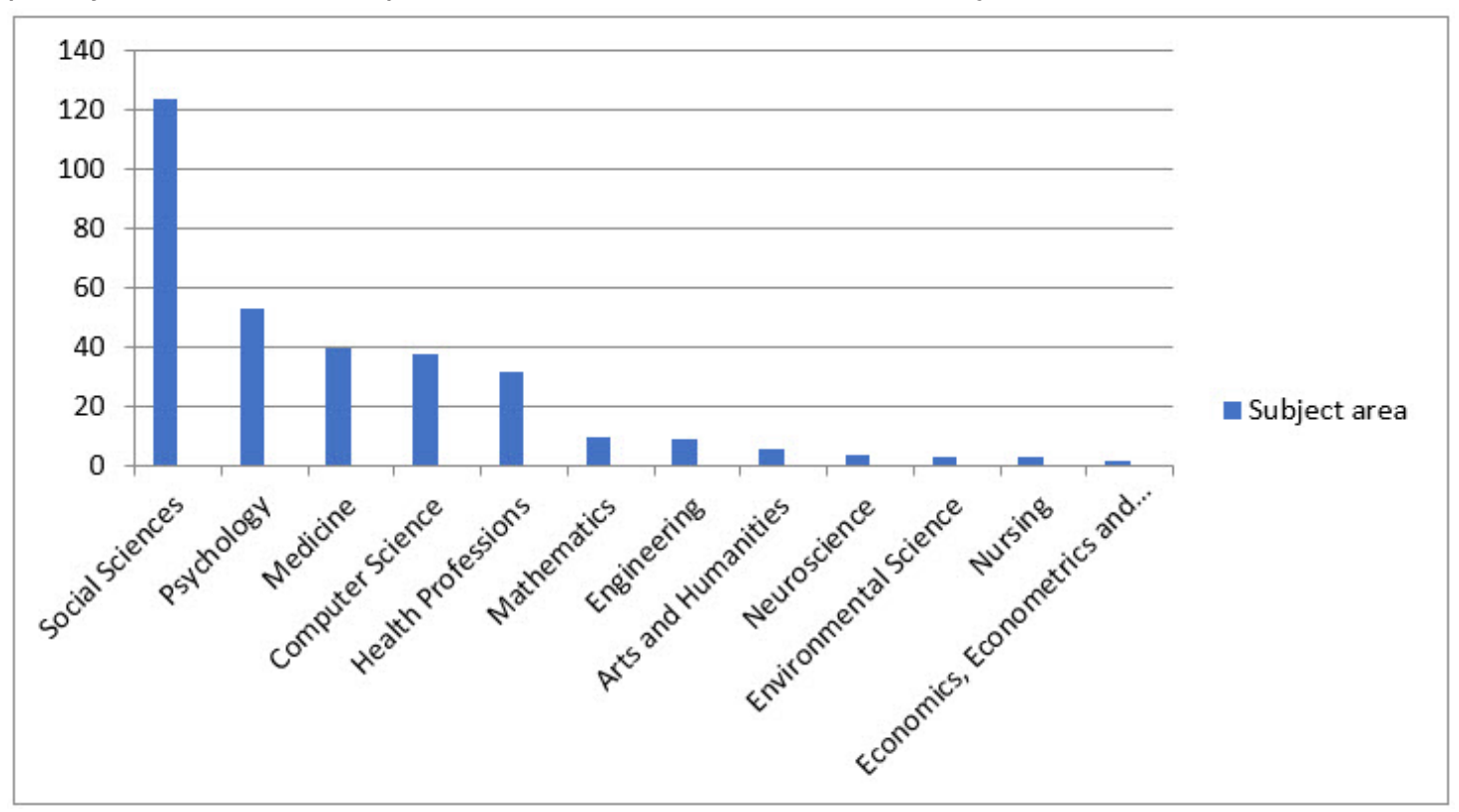

Figure 4 demonstrates the distribution of the published documents based on the subject area. Subject areas with one frequency value were not included in the figure. Results revealed that social sciences, psychology, medicine, computer science, health professions and mathematics were the most frequently studied subject areas in studies related with learning environment and special education.

\section{Distribution of the published documents based on the keywords}

Figure 5.

Distribution of the published documents based on the keywords

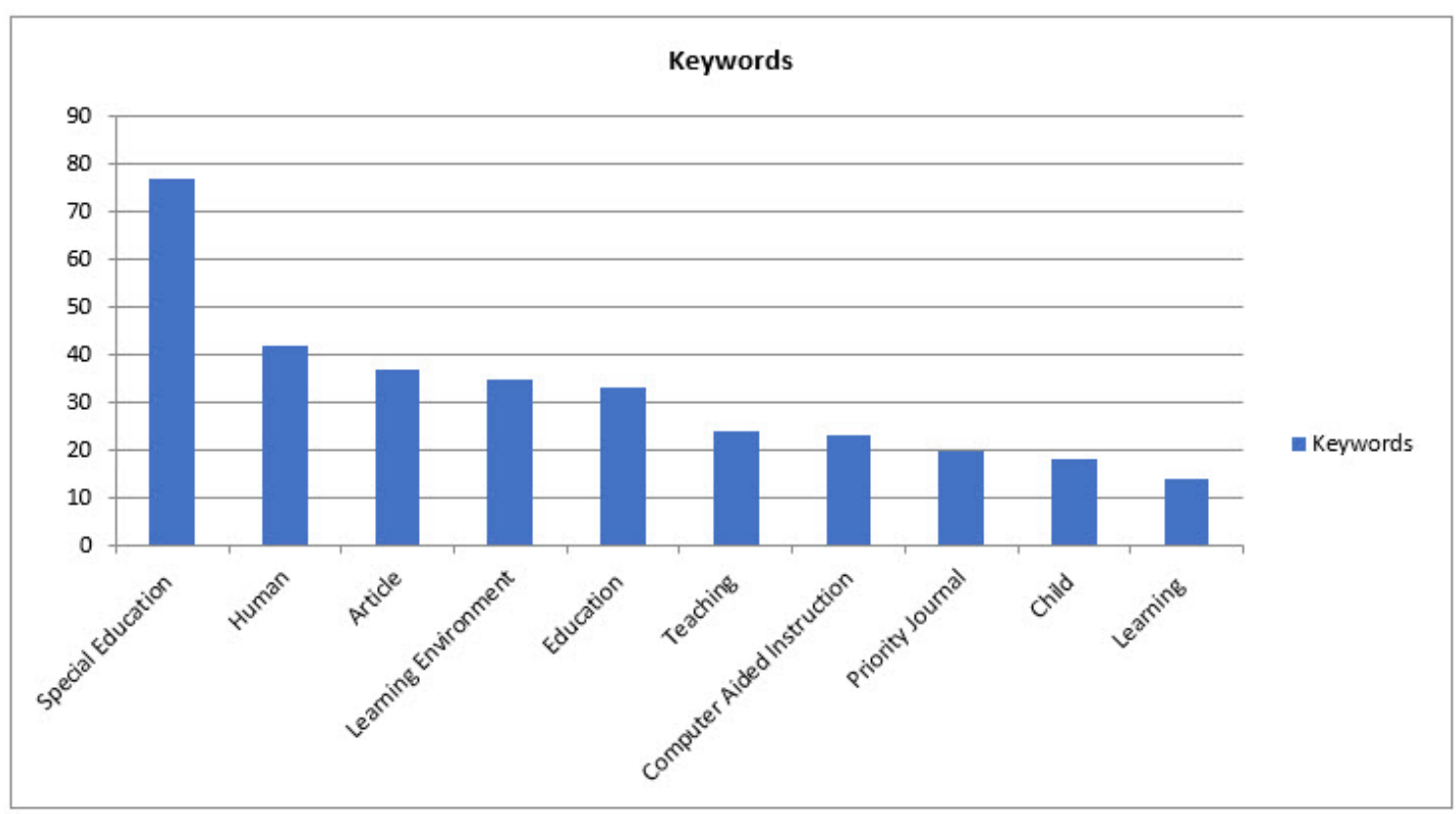

Distribution of the published documents based on the keywords is shown in Figure 5. The top 10 frequently used keywords are involved in the figure. Results indicated that 'special education', 'human', 'article', 'learning environment', 'education', 'teaching' and 'computer-aided instruction' were the most frequently mentioned keywords in the papers about learning environment and special education. 


\section{Distribution of the published documents based on the language}

\section{Table 3.}

Language of the published documents

\begin{tabular}{lll}
\hline Language & $f$ & $\%$ \\
\hline English & 175 & 97.22 \\
Portuguese & 4 & 2.22 \\
Turkish & 2 & 1.11 \\
Japanese & 1 & 0.56 \\
Spanish & 1 & 0.56 \\
Total & $\mathbf{1 8 0}$ & $\mathbf{1 0 0}$ \\
\hline
\end{tabular}

Table 3 shows the distribution of languages of the papers about learning environment and special education. According to the results, majority of the published documents were in English ( $f=175,97.22 \%$ ). There were four documents in Portuguese (2.22\%), two documents in Turkish (1.11\%), one document in Chinese and Spanish (0.56\%).

\section{The most cited documents on research methods and special education in Scopus}

\section{Table 4.}

Most cited documents

\begin{tabular}{|c|c|c|c|c|c|}
\hline No. & Document title & Author(s) & Year & Source & Cited by \\
\hline 1. & $\begin{array}{l}\text { Intemational trends in inclusive education: } \\
\text { The continuing challenge to teach each } \\
\text { one and everyone }\end{array}$ & Ferguson, D.L. & 2008 & $\begin{array}{l}\text { Eloropecn Jownal of } \\
\text { Special Neede Educa- } \\
\text { tion }\end{array}$ & 101 \\
\hline 2. & $\begin{array}{l}\text { Mobile learning technology based on iOS } \\
\text { devices to support students with special } \\
\text { education needs }\end{array}$ & $\begin{array}{l}\text { Fermandez-Lopez, } \\
\text { A., Rodriguez-For- } \\
\text { tiz, M.J., Rodri- } \\
\text { guez-Almendros, } \\
\text { ML., Martinez-Se- } \\
\text { gura, M.J. }\end{array}$ & 2013 & $\begin{array}{l}\text { Computers and Edh- } \\
\text { cation }\end{array}$ & 93 \\
\hline 3. & Full inclusion and students with autigm & $\begin{array}{l}\text { Mesibov, GB, } \\
\text { Shea, V }\end{array}$ & 1996 & $\begin{array}{l}\text { Jownal of Autism and } \\
\text { Developmental Disor- } \\
\text { ders }\end{array}$ & 75 \\
\hline 4. & $\begin{array}{l}\text { Virtual spaces: Employing a synchronous } \\
\text { online classroom to facilitate student en- } \\
\text { gagement in online learning }\end{array}$ & $\begin{array}{l}\text { McErien, JL., } \\
\text { Jones, P., Cheng, R. }\end{array}$ & 2009 & $\begin{array}{l}\text { International Review } \\
\text { of Reseavch in Open } \\
\text { and Distance Lean- } \\
\text { ing }\end{array}$ & 66 \\
\hline 5. & $\begin{array}{l}\text { Social integration and severe disabilities: } \\
\text { A longinudinal analysis of child outcomes }\end{array}$ & $\begin{array}{l}\text { Cole, D.A., Meyer, } \\
\text { L.H. }\end{array}$ & 1991 & $\begin{array}{l}\text { The Jownal of Spe- } \\
\text { cial Ecucation }\end{array}$ & 62 \\
\hline 6. & $\begin{array}{l}\text { Reducing poverty through preschool inter- } \\
\text { ventions }\end{array}$ & $\begin{array}{l}\text { Duncan, GJ., Lud- } \\
\text { wig, J., Magnuson, } \\
\text { K.A. }\end{array}$ & 2007 & Futwe of Children & 58 \\
\hline 7. & $\begin{array}{l}\text { Effective Special Education in Regular } \\
\text { Classes }\end{array}$ & $\begin{array}{l}\text { Wang, MC., Birch, } \\
\text { J.W. }\end{array}$ & 1984 & Exceptional Chlatwen & 47 \\
\hline 8. & $\begin{array}{l}\text { Planning for effective co-teaching: The } \\
\text { key to successful inclusion }\end{array}$ & $\begin{array}{l}\text { Walther-Thomas, } \\
\text { C., Bryant, M., } \\
\text { Land, S. }\end{array}$ & 1986 & $\begin{array}{l}\text { Remedial and Special } \\
\text { Education }\end{array}$ & 46 \\
\hline 9. & $\begin{array}{l}\text { Student teachers' perceptions about inclu- } \\
\text { give classroom teaching in Northem Ire- } \\
\text { land prior to teaching practice experience }\end{array}$ & $\begin{array}{l}\text { Lambe, J., Bones, } \\
\text { R. }\end{array}$ & 2006 & $\begin{array}{l}\text { Europecn Jownal of } \\
\text { Special Neede Educa- } \\
\text { tion }\end{array}$ & 42 \\
\hline 10. & $\begin{array}{l}\text { Using a participatory action research ap- } \\
\text { proach to create a universally designed in- } \\
\text { clusive high school science course: A case } \\
\text { stud }\end{array}$ & $\begin{array}{l}\text { Dymond, S. ., } \\
\text { Renzaglia, A, } \\
\text { Rosenstein, A., (...), } \\
\text { Niswander, V, Gil- } \\
\text { son, C.L. }\end{array}$ & 2006 & $\begin{array}{l}\text { Reseavch and Prac- } \\
\text { tice for Persons with } \\
\text { Severe Disabilities }\end{array}$ & 38 \\
\hline
\end{tabular}


Table 4 demonstrates the most cited documents on learning environments and special education. The 10 most frequently cited documents are included. The article with the highest citations was published in 2008 and it has 101 citations. This result is followed by an article with 93 citations in 2013; an article with 75 citations in 1996 and an article with 66 citations in 2009. When the subjects of the most cited articles are examined, it is seen that they mostly focus on inclusion, learning and social integration of the individuals with special needs.

\section{Discussions}

Evaluation in special education is very important in terms of determining the suitability of the student for special education, identifying the distinguishing characteristics of the student and determining and presenting the existing performance level of the student. Therefore, a systematic review of the scientific research conducted in this area is of great importance and the present study aimed to review the studies on learning environments and special education and reveal the trends in these studies through content analysis and citation analysis. According to the results, the number of published papers showed a regular increase especially after 2005 when compared to previous years and the highest number of publication is in 2017 with 23 publications. This might be related with the increase legal foundations, regulations and supervisions of special education practices since these make it obligatory to provide appropriate learning environments for the students with special needs, and therefore, the number of publications increased (Fulcher, 2015; Kauffman and Badar, 2014).

Furthermore, the highest number of publications were in European Journal of Special Needs Education, Lecture Notes in Computer Science, International Journal of Inclusive Education and Remedial and Special Education with five publications. Results indicated that the United States was the first country with 65 publications related with learning environments and special education in Scopus. In line with this result, Demirok, Baglama and Besgul (2015) found that the United States has the highest number of publication regarding special education. In addition, the United Kingdom, Norway, Brazil and Sweden were the other countries with the highest number of publications. According to the results, articles, conference papers and books were highly preferred by the researchers for publishing. Results revealed that social sciences, psychology, medicine, computer science, health professions and mathematics were the most frequently studied subject areas in studies related with learning environment and special education. Results indicated that 'special education', 'human', 'article', 'learning environment', 'education', 'teaching' and 'computer-aided instruction' were the most frequently used keywords in the published documents related with learning environment and special education in Scopus. These results might be related with the interdisciplinary nature of the field of special education (Hernandez, 2013).

Resulst regarding the languages of the published documents showed that majority of the published documents were written in English. Lastly, the article with the highest citations was published in 2008 with 101 citations. This result is followed by an article with 93 citations in 2013; an article with 75 citations in 1996 and an article with 66 citations in 2009. When the subjects of the most cited articles are examined, it is seen that they mostly focus on inclusion, learning and social integration of individuals with special needs, which is very important and prevalently studied research subjects in special education (Allen and Cowdery, 2014; Baglama and Demirok, 2016; Kirby, 2017; Uzunboylu, Uluc and Ozcan, 2017).

\section{Conclusions and recommendations}

In conclusion, the present study provided a comprehensive review for the studies related with learning environments and special education to provide a framework for the current situation and trends in these studies. Recommendations are provided for further research and practices:

- Different academic databases should be analysed in order to reveal the trends in published papers on learning environments and special education.

- Guidelines for how to constitute appropriate learning environments for individuals with special needs might be emphasised more in scientific research for researchers and professionals of special education.

- Other content analysis criteria including research sample, topic, method and number of authors might be used to point out these tendencies in the published documents related with learning environment and special education.

- Instead of revealing the current situation, further research might carry out studies with different research methods in order to provide comparative results. 
Uzunboylu, H., \& Akçamete, G. (2020). A content and citation analysis of the studies on learning environments and special education, International Journal of Cognitive Research in Science, Engineering and Education (IJCRSEE), 8(2), 95-104

\section{Conflict of interests}

The authors declare no conflict of interest.

\section{References}

Akcamete, G., Kayhan, N. \& Yildirim, A. (2017). Scale of professional ethics for individuals working in the field of special education: validity and reliability study. Cypriot Journal of Educational Sciences, 12(4), 202-217. https://10.18844/cjes. v12i4.2902

Allen, E. K. \& Cowdery, G. E. (2014). The exceptional child: inclusion in early childhood education. Nelson Education. https:/l cengage.com.au/product/title/the-exceptional-child-inclusion-in-early-chil/isbn/9781285432373

Ardic, A. (2014). Bireysel farkliliklar. Ankara, Turkey: Kok Yayincilik. http://www.kokyayincilik.com.tr/

Atilgan, D., Atakan, C. \& Bulut, B. (2008). Turkce kutuphanecilik dergilerinin atif analizi [Citation analysis of Turkish libraries] Turk Kutuphan-eciligi, 22(4), 392-413. Retrieved from: https://www.researchgate.net/publication/277158779_Turkce_ Kutuphanecilik_Dergilerinin_Atif_Analizi

Avcioglu, H. (2016). Ozel gereksinimi olan bireylerin degerlendirilmesi. Ankara, Turkey: Vize Yayincilik. Retrieved from: https:/l vizeakademik.com.tr/ozel-gereksinimi-olan-bireylerin-degerlendirilmesi

Baglama, B. \& Demirok, M. S. (2016). Opinions of mothers of children with autism spectrum disorder towards special education support and services. International Journal of Educational Sciences, 15(1-2), 279-289. Retrieved from: htt ps://10.31901/24566322.2016/15.1-2.30

Bateman, D. F. \& Bateman, C. F. (2014). A principal's guide to special education. Council for Exceptional Children. Retrieved from: https://eric.ed.gov/?id=ED455624b

Cohen, L., Manion, L. \& Morrison, K. (2007). Research methods in education (6 $6^{\text {th }}$ ed.). New York, NY: Routledge. Retrieved from: https://is/mblogblog.files.wordpress.com/2016/05/rme-edu-helpline-blogspot-com.pdf

Coskun, Z., \& Mitrani, C. (2020). An instructional design for vocabulary acquisition with a hidden disability of dyslexia. Cypriot Journal of Educational Sciences, 15(2), 305-318. https://doi.org/10.18844/cjes.v15i2.4671

Crockett, J. B. \& Kauffman, J. M. (2013). The least restrictive environment: its origins and interpretations in special education. Taylor and Francis. Retrieved from: https://www.taylorfrancis.com/books/9781410603722

Demirok, M. S., Baglama, B. \& Besgul, M. (2015). A content analysis of the studies in special education area. Procedia: Social and Behavioral Sciences, 197, 2459-2467. https://doi.org/10.1016/j.sbspro.2015.07.311

Dixon, F. A., Yssel, N., McConnell, J. M. \& Hardin, T. (2014). Differentiated instruction, professional development, and teacher efficacy. Journal for the Education of the Gifted, 37(2), 111-127. https://doi.org/10.1177/0162353214529042

Fulcher, G. (2015). Disabling policies? A comparative approach to education policy and disability. Routledge. Retrieved from: https://www.routledge.com/Disabling-Policies-A-Comparative-Approach-to-Education-Policy-and-Disability/Fulcher/p/ book/9781315668253

Gozun, O. \& Yikmis, A. (2004). Ogretmen adaylarinin kaynastirma konusunda bilgilendirilmelerinin kaynastirmaya yonelik tutumlarinin degisimindeki etkililigi [The effectiveness of the teacher candidates' being informed about mainstreaming on the change in their attitudes towards mainstreaming]. Ankara Universitesi Egitim Bilimleri Fakultesi Ozel Egitim Dergisi, 5(2), 65-77. https://doi.org/10.1501/Ozlegt_0000000081

Gulbahar, Y. \&Alper, A. (2009). Ogretim teknolojileri alaninda yapilan arastirmalar [Research in the field of teaching technologies]. Ankara Universitesi Egitim Bilimleri Fakultesi Dergisi, 42(2), 93-111. https://doi.org/10.1501/Egifak_0000001178

Hernandez, S. J. (2013). Collaboration in special education: its history, evolution, and critical factors necessary for successful implementation. Online Submission, 3(6), 480-498. Retrieved from: https://eric.ed.gov/?id=ED544122

Howe, K. R. \& Miramontes, O. (2015). The ethics of special education. New York, NY: Teachers College Press. Retrieved from: https://www.worldcat.org/title/ethics-of-special-education/oclc/1022977104

Inaltekin, T. (2020). Examining secondary students' perceptions of the technology-based learning and teaching in science courses. World Journal on Educational Technology: Current Issues, 12(2), 71-83. https://doi.org/10.18844/wjet. $\mathrm{v} 12 \mathrm{i} 2.4628$

Ince, M. \& Costu, B. (2018). The effect of informal learning environment upon students' understanding of science-technologysociety-environment. New Trends and Issues Proceedings on Humanities and Social Sciences, 4(9), $22-37$. https://10.18844/prosoc.v4i9.3039

Kauffman, J. M. \& Badar, J. (2014). Instruction, not inclusion, should be the central issue in special education: an alternative view from the USA. Journal of International Special Needs Education, 17(1), 13-20. Retrieved from: https://eric. ed.gov/?id=EJ1090816

Kaya, Z., Anay, M., Abali, G., Karasu, G. \& Girgin, C. (2017). Acquaintance with profession: using internship as a tool for. Contemporary Educational Researches Journal, 7(3), 134-143. https://10.18844/cerj.v7i3.2649

Kirby, M. (2017). Implicit assumptions in special education policy: promoting full inclusion for students with learning disabilities. Child \& Youth Care Forum, 46(2), 175-191. Retrieved from: https://link.springer.com/article/10.1007/s10566-0169382-X

Leung, X. Y., Sun, J. \& Bai, B. (2017). Bibliometrics of social media research: a co-citation and co-word analysis. International Journal of Hospitality Management, 66, 35-45. https://doi.org/10.1016/j.ijhm.2017.06.012

Lewis, R. B., Wheeler, J. J. \& Carter, S. L. (2017). Teaching students with special needs in general education classrooms. Pearson. Retrieved from: https://www.amazon.com/Teaching-Students-Special-Education-Classrooms-ebook/dp/ B01F7R91Q0

Milli Egitim Bakanligi. (2006). Ozel egitim hizmetleri yonetmeligi [Special education services regulation]. Retrieved from: http:// orgm.meb.gov.tr/meb_iys_dosyalar/2012_10/10111226_ozel_egitim_hizmetleri_yonetmeligi_son.pdf

Mostafa, R. A. (2017). Creating a positive learning environment for adult. International Journal of Learning and Teaching, 9(3), 378-387. https://10.18844/ij|t.v9i3.525

Ozcan, D. \& Merdan, F. (2016). Examination of parents' anxiety about their gifted children's education. Global Journal of Psychology Research: New Trends and Issues, 6(2), 63-69. https://10.18844/gjpr.v6i2.638 
Uzunboylu, H., \& Akçamete, G. (2020). A content and citation analysis of the studies on learning environments and special education, International Journal of Cognitive Research in Science, Engineering and Education (IJCRSEE), 8(2), 95-104

Sabayleh, O., \& Alramamneh, A. (2020). Obstacles of implementing educational techniques in special education centres from autism teachers' perspective. Cypriot Journal of Educational Sciences, 15(2), 171-183. https://doi.org/10.18844/cjes. v15i2.4485

Sahin, M. \& Koca, S. (2017). European Union lifelong learning key competences in early childhood education. International Journal of Innovative Research in Education, 3(3), 135-142. https://10.18844/ijire.V3i3.1854

Sancar, I., Tozkoparan, S., \& Odabasi, H. (2017). Use of mobile technologies in special education: A content analysis. Journal of Education and Special Education Technology, 3(1), 1-12. https://doi.org/10.18844/jeset.v3i1.3890

Taylor, S. J. (2004). Caught in the continuum: a critical analysis of the principle of the least restrictive environment. Research and Practice for Persons with Severe Disabilities, 29(4), 218-230. https://doi.org/10.2511/rpsd.29.4.218

Uzunboylu, H. \& Beheshti, M. (2017). An investigation through content analysis in infographics. Turkish Online Journal of Design Art and Communication, 7(4), 655-666. https://doi.org/10.7456/10704100/011

Uzunboylu, H., Baglama, B., Ozer, N., Kucuktamer, T. \& Kuimova, M. V. (2017). Opinions of school counselors about bullying in Turkish high schools. Social Behavior and Personality, 45(6), 1043-1055. https://doi.org/10.2224/sbp.6632

Uzunboylu, H., Uluc, M. \& Ozcan, D. (2017). Educational strategies to be acquired by teachers in dealing with attention deficit and hyperactivity disorder students. Ponte, 73(8), 419-431. https://10.21506/j.ponte.2017.8.30

Vasiliene-Vasiliauskiene, V., Vasilis Vasiliauskas, A., Meidute-Kavaliauskiene, I., \& Sabaityte, J. (2020). Peculiarities of educational challenges implementing project-based learning. World Journal on Educational Technology: Current Issues, 12(2), 136-149. https://doi.org/10.18844/wjet.v12i2.4816

Zaid, M. (2020). Code-switching: The case of "Israeli Arab" students at the Arab American University-Palestine. Global Journal of Foreign Language Teaching, 10(1), 20-31. https://doi.org/10.18844/gjftt.v10i1.4409 